\title{
On the Causality between Trade Credits and Imports: Evidence and Possible Implication for Trade Penalties on Debt Defaults
}

\author{
YOTHIN JINJARAK
}

\author{
NTU, Singapore
}

\begin{abstract}
This study investigates the association between trade credits and imports of developing countries. Made available by its creditors, the main function of trade credits is to facilitate cross-border transactions of goods and services. This study finds that the reliance of imports on trade credits varies across regions and income: towards the end of the 1990s, the trade credits to imports ratio ranged from 0.20 for East Asia \& the Pacific to 0.87 for Africa, and from 0.24 for high-income countries to 0.79 for low-income countries. Applying panel and cross-country estimation, we find that past trade credits help predict current imports, but past imports do not alter the future path of trade credits. Further, the positive association between trade credits and imports is larger for countries more dependent upon trade credits. The findings support the notion that countries make debt repayments to avoid any potential disruption on the line of trade credits. We also find that the trade credits penalty could materialize within less than two quarters.
\end{abstract}

KEY WORDS: Debt repayment, international loans, trade finance JEL Classification: F10, F20, F32, F34, O10

\section{Overview}

Approximately half of world trade is conducted on credit, which can be defined as when a supplier gives to its foreign buyer a trade-financing loan financed by

Correspondence Address: Yothin Jinjarak, Division of Economics, S3-B2A-06 Nanyang Technological University, Singapore 639798. Email: yjinjarak@ntu.edu.sg 
commercial banks on both sides of the transaction. ${ }^{1}$ For importers, especially in developing countries, trade financing from foreign suppliers is an essential source of external finance. By the end of 2003, roughly a quarter of the developing countries' total cross-border liabilities to foreign banks was based on trade credits. ${ }^{2}$ Most commonly, the reference to trade credits in international economics is in the context of whether or not they can work as a trade penalty to enforce sovereign debt repayments. As a result, recurring interests in trade credits are motivated by the observation that turbulent periods in the financial sector (i.e. debt- and financial crises) are often associated with difficulties in financing cross-border commercial trade of debtor countries.

As trade liberalization has become a global phenomenon, the necessity of trade credits has inevitably become a challenge to policy making. Following the financial crises in the late 1990s, Krueger (2002) pointed to the benefits of a debt restructuring mechanism that will facilitate a debtor country's trade-financing need in order to limit the degree of economic dislocation. It is quite promising then, that a better understanding of how trade credits function will also help us to address the more important question of why a country should repay its sovereign debt in the first place. In their seminal contribution, Bulow \& Rogoff (1989) succinctly put that a country has an incentive to make some repayments on its debts in order to avoid its line of trade credits being discontinued and fully gain from international trade: ${ }^{3}$

...Very short term trade credits, such as bankers' acceptances and letters of credits, are enormously important in reducing transactions costs in international trade. International banks can exploit economies of scale in monitoring costs to facilitate transactions between importers and exporters who sometimes know very little about one another. (Bulow \& Rogoff, 1989: 159)

Dictated by data limitation, the conceptual proposition of Bulow \& Rogoff has commanded only a handful of empirical tests. Rose (2005) reports that following the Paris Club sovereign debt rescheduling, bilateral trade between debtor

\footnotetext{
${ }^{1}$ There are two types of trade credits: (a) standard letter of credits (guaranteed payment to the exporter promptly after its good has been shipped); (b) standby letter of credits (guaranteed payment to the exporter after the importer fails to honor its obligations in the contract). See also USDOC (2002) and Palmer (1999). In a simple arrangement of international trade transactions, after a supplier contracts to supply goods to a foreign buyer, there is a parallel trade financing loan agreement in which a delegated bank lends on behalf of the supplier to the foreign buyer's bank. The loan is normally guaranteed by an export-credit agency of the supplier's country (and/or a lead bank, if the loan is syndicated).

${ }^{2}$ Calculated from the external debts statistics of the joint BIS-IMF-OECD-World Bank network, using the stock of trade credits as a percentage of consolidated total liabilities to banks (which are nationals of (i.e. headquartered in) industrial countries and report their claims on a worldwide consolidated basis, both short term and long term).

${ }^{3}$ Other considerations on repayment incentives include Eaton \& Gersovitz (1981), Ozler (1993), and Kletzer \& Wright (2000). For analyses on contract enforcement in international trade, see Marin \& Schnitzer (2002), Greif (1993), Greif et al. (1994), and Dixit (2003). For studies on the importance of commercial credits and finance in the context of comparative advantage in international trade, see Eaton (1986), Kletzer \& Bardhan (1987), Beck (2002), Klimenko (2002), Svaleryd \& Vlachos (2002, 2005).
} 
countries and their creditors dropped by $8 \%$ a year and persisted for around 15 years. Rose argues that the subsequent decline in international trade is a result of either creditors seeking to punish and deter default, or a result of trade credits simply drying up upon default. Based on their gravity-type estimation, Rose \& Spiegel (2002) note that the high correlation found between cross-border trade and lending ${ }^{4}$ corroborates the possibility that a debtor nation tends to borrow more from a creditor country with whom they share more international trade ties.

It is plausible then, other things being equal, that an increase in bilateral trade would increase the availability of trade credits a country receives from its trading partners as a part of its trade and financial networks. Sarria-Allende et al. (forthcoming) finds that although provision of trade credit increases immediately after the crisis, it consequently collapses in the following months and years. Hence, while it is possible that past levels of trade credits could help predict current levels of imports, it is also conceivable that past imports would help predict current levels of trade credits. That is, do trade credits Granger-cause imports, or imports Granger-cause trade credits: in order to secure short-term loans to finance their imports, are the borrowing countries financially constrained in international capital markets? If the causality runs from volume of imports to provision of trade credits, the presence of trade credits would not aid the repayment incentive, and the ability of a debtor country to fully gain from international trade would not be affected by it in any case.

The purpose of this paper is to empirically evaluate the association between trade credits and imports. Anticipating our main findings, we find that past trade credits help predict current imports, but past imports do not alter the future path of trade credits. Trade credits have a larger impact on countries that display greater reliance on them. The next section provides preliminary discussion of the data. The third section summarizes the panel and cross-country estimation. The fourth section concludes.

\section{Preliminary Discussion}

The Appendix provides the data source and country list used in our sample. Dictated by data availability, the sample covers 111 countries over the period 1991-2003. Figure 1(a) compares trade credits for periods 1991-93, 1994-96, and 2001-03 for the developing countries segregated into six regions. The record is mixed: trade credits increased for East Asia \& the Pacific and East Europe $\&$ Central Asia, but declined for Latin America \& the Caribbean and Middle East \& North Africa. Towards the early 2000s, East Asia \& the Pacific registered the highest amount of trade credits, totaling on average US $\$ 4.8$ billion a year. The region also registered the highest amount of imports from industrial countries (see Figure $1(\mathrm{~b})$ ). Further insight about these developments is gained by comparing trade credits/imports ratio. Although the salient feature of the last 20 years has been the phenomenal increase in cross-border trade, as evident in Figure 1(c), a comparison of trade credits/imports over the decade reveals that some regions

\footnotetext{
${ }^{4} \mathrm{An}$ increase in bilateral trade of $1 \%$ is associated with an increase in bilateral lending (measured by international banking claims) of over $0.5 \%$ (Rose \& Spiegel, 2002).
} 


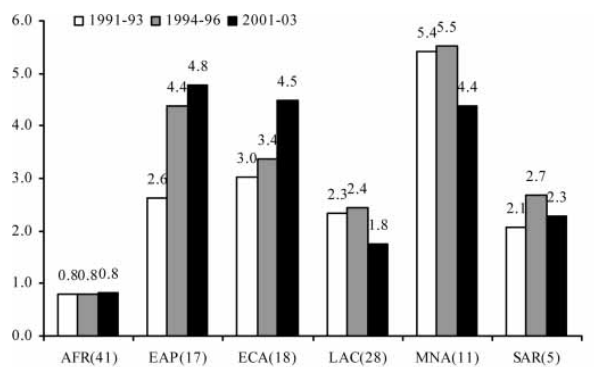

(a)

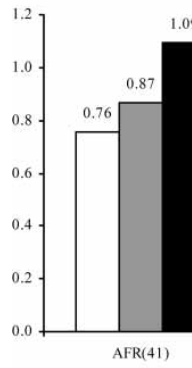

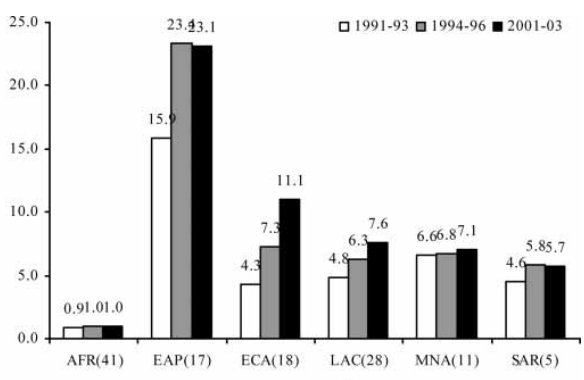

(b)

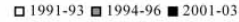

Figure 1. (a) Trade Credits (billion US\$) by region. (b) Imports (billion US\$) by region. (c) Trade credits to imports ratio by region

rely more on trade credits than others. While Africa received trade credits on average of US $\$ 0.8$ billion a year, that amount is almost equal to the region's total import amount from industrial countries. On the other hand, trade credits feature only a fifth of the total imports for East Asia \& the Pacific region.

Figures $2(\mathrm{a})-(\mathrm{c})$ report trade credits, imports, and trade credits/imports ratio segregated by income groups. As shown in Figures 2(a) and 2(b), the amount of trade credits received and goods imported were positively associated with the level of income. Further, while the trade credits/imports ratio decreased with income, only the low-income group displayed greater dependence on trade credits (see Figure 2(c)). From 1991 to 2003, the trade credits/imports ratio of the lowincome group increased by almost $100 \%$, whereas the ratio dropped in other income groups.

Overall, the preliminary evidence discussed thus far suggests that the association between imports and trade credits differs across income groups and geographical regions. To gain further insights, we apply panel and cross-country regressions in the next section.

\section{Empirical Analysis}

\section{Panel Data Estimation}

The objective is to discover any causal association between trade credits (henceforth denoted by $x$ ), and imports (denoted by $y$ ). Suppose there are $N$ countries 


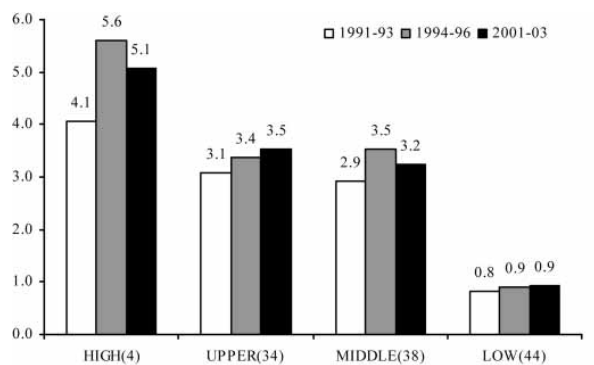

(a)

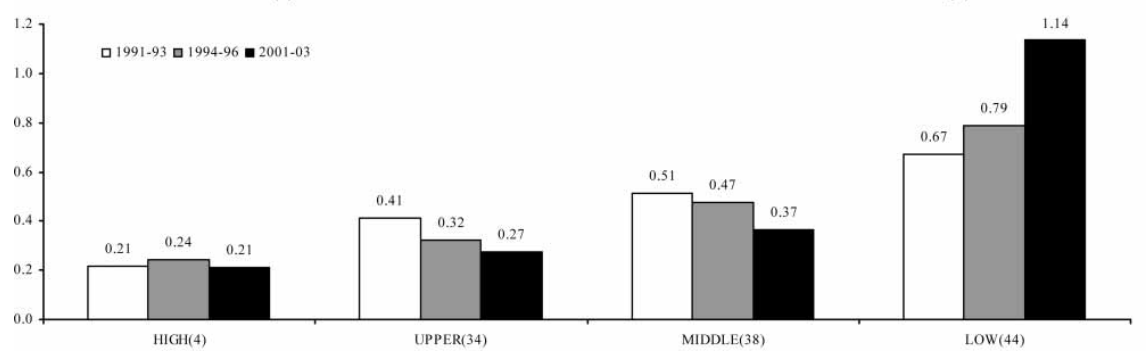

(c)

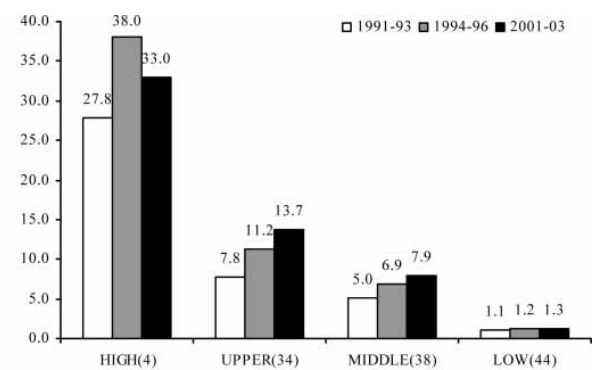

(b)

Figure 2. (a) Trade credits (billion US\$) by income group. (b) Imports (billion US\$) by income group. (c) Trade credits to imports ratio by income group

(cross-sectional observations) and $T$ time periods of data available. Let $i$ be the index for countries and $t$ the time periods. Allowing for a country effect $\left(f_{i}\right)$ for country $i$, the model for estimation is:

$$
y_{i t}=\alpha_{0}+\sum_{l=1}^{m} \alpha_{l} y_{i t-l}+\sum_{l=1}^{m} \delta_{l} x_{i t-l}+f_{i}+u_{i t}
$$

where all variables are in logs. The dynamic panel data estimation of equation (1) is characterized by autocorrelation due to the presence of lagged dependent variables $\left(y_{i t-l}\right)$ among the explanatory variables and the country effects. ${ }^{5}$ To obtain consistent coefficient estimates, we apply the dynamic panel data GMM estimation of Arellano \& Bond (1991) to equation (1) as the following. In the first step, we examine the lag length $(m)$ that is at least sufficient to characterize the data. Following Holtz-Eakin et al. (1988) we denote by $M$ the relatively large value of $m$ used for initial estimation of the model. We re-estimate the model with $m=M-1$. If the increase in the sum of squared residuals is large, then $m=M$ is accepted. If the increase is 'small,' then we try $m=M-2$, and with successively smaller lag lengths until one is rejected by the data, or $m=0$. In the second step, we examine whether $x$ causes $y$ by testing the joint hypothesis that $\delta_{1}=\delta_{2}=\cdots=\delta_{m}=0$. Essentially, our causality test is a test of whether the lags

${ }^{5}$ See for example Baltagi (2001) for a comprehensive survey on econometric issues surrounding dynamic panel data framework. 
of trade credits enter into the imports equation, and the test itself is conditional on the chosen lag length.

To carry out the test, we use statistics on trade credits extended by industrialcountry creditors to developing countries. The amount of trade credits is recorded twice a year (semi-annually) and includes all official and officially-supported trade credits, summing together financial and buyer credits arranged by the industrial countries' commercial banks. These credits are normally guaranteed or insured by official export credits agencies. Due to a major change in accounting procedures and a discontinuity of the trade credits series in 1998, we are forced to employ the data up to only that year. When we matched the trade credits series with the volume of goods imported from the industrial countries, there was usable information on 111 developing countries covering nine semi-annual periods from 1992 to 1997.

We begin by estimating equation (1) with three lags $(m=3)$ of each of the right-hand side variables, so that we end up with five years of data per country. ${ }^{6}$ We first test for parameter stationarity, i.e. both the country effects $\left(f_{i}\right)$ and the lag parameters in equation (1) are the same for each period. When equation (1) is estimated using $m=3$, the minimized value of the $\chi^{2}$ test statistic, which, following Holtz-Eakin et al. (1988), we denote $Q$, is equal to 40.77 , and has 34 degrees of freedom. Because the critical value of the $\chi_{34}^{2}$ at $1 \%$ level is 56.06 , we cannot reject parameter stationarity and that the appropriate specification of the imports equation is a dynamic panel data model containing at least three lags each of imports and trade credits. To find a lag length that is at least sufficient to characterize the data, we impose $m=2$. The value of the $Q$ statistic is 58.29. Comparing this to the value of $Q$ when $m=3$, we find that the value of the appropriate (lag selection) test statistic, ${ }^{7}$ denoted $L$, is equal to 58.29 (restricted Q) minus 40.77 (unrestricted Q), or 17.53, and has 2 degrees of freedom (we are restricting the third lag of each variable). Because the critical value of the $\chi_{2}^{2}$ distribution at the $1 \%$ level is 9.21, one can reject equation (1) with two lags. The model with three lags for each variable adequately characterizes the dynamic association between imports and trade credits in our sample.

Table 1 reports the panel data estimates for the imports and trade credits equations assuming parameter stationarity, but with no other constraints

\footnotetext{
${ }^{6}$ Four semiannual periods were lost in constructing lags and taking first differences. Note that the econometric issues involving unbalanced panels are not relevant here because of $T=5$ for all countries in our sample. Given small $T$ (length of time series) and large $N$ (number of countries) of the sample, potential bias caused by non-stationary panels is also not major. See for example Phillips \& Moon (2000) for a simulation analysis on unit roots and co-integration in panel data where there are large $N$ and large T. Further, Judson \& Owen (1999) show that GMM estimation on equation (1) performs well for the dynamic panel data model when $T<10$.

${ }^{7}$ Holtz-Eakin et al. (1988) provides derivation of the test. They show how linear constraints in the dynamic panel model can be tested in the conventional way by noting that the difference in the constrained and unconstrained sum of squared residuals has a $\chi^{2}$ distribution with degrees of freedom equal to the degrees of freedom of the unconstrained equation minus the degrees of freedom of the constrained equation.
} 


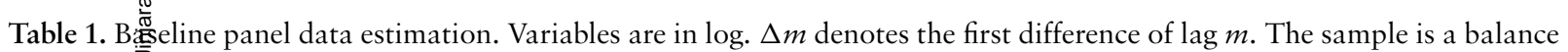
panel data. covering semiannual periods from 1992 to 1997 . Estimation uses the dynamic panel data framework. Standard orrors are in parentheses. Symbol ${ }^{*}\left[{ }^{* *},{ }^{* * *}\right]$ denotes statistical significance at the $10 \%[5 \%, 1 \%]$ level

\begin{tabular}{|c|c|c|c|c|}
\hline Dependen ڤ్̉variable: & $\Delta 1$ (Imports) & $\Delta 1$ (Trade Credits) & $\Delta 1$ (Imports) & $\Delta 1$ (Trade Credits) \\
\hline \multicolumn{5}{|l|}{ Explanatory Variable: } \\
\hline$\Delta 1$ (Imports) & $-0.176(0.073)^{*}$ & $-0.004(0.121)$ & $-0.146(0.073)^{*}$ & $-0.063(0.112)$ \\
\hline$\Delta 2$ (Imports) & $-0.183(0.049)^{* *}$ & $-0.037(0.128)$ & $-0.155(0.049)^{* *}$ & $0.018(0.123)$ \\
\hline$\Delta 3$ (Imports) & $-0.249(0.045)^{* *}$ & $0.233(0.125)$ & $-0.232(0.045)^{* *}$ & $0.100(0.091)$ \\
\hline$\Delta 1$ (Trade Credits) & $0.236(0.063)^{* *}$ & $0.133(0.084)$ & $0.240(0.061)^{* *}$ & $0.109(0.073)$ \\
\hline$\Delta 2$ (Trade Credits) & $0.050(0.063)$ & $0.099(0.055)$ & $0.069(0.063)$ & $0.106(0.049)^{*}$ \\
\hline$\Delta 3$ (Trade Credits) & $0.078(0.067)$ & $-0.149(0.043)^{* *}$ & $-0.035(0.060)$ & $-0.145(0.041)^{* *}$ \\
\hline Endogenous explanatory variable & Trade Credits & Imports & n.a. & n.a. \\
\hline Observations & 555 & 555 & 555 & 555 \\
\hline Number of Countries & 111 & 111 & 111 & 111 \\
\hline
\end{tabular}


imposed. The Arellano \& Bond (1991) procedure is used to both equations, treating the right-hand side as endogenous and exogenous in the first and second panel of Table 1, respectively. Denote $\Delta m$ as lag $m$ of the first difference, we use lags of trade credits from dated $(t-4)$ and earlier as instruments for $\Delta 1$ (Trade Credits), $\Delta 2$ (Trade Credits), and $\Delta 3$ (Trade Credits) in the imports equation (and in a similar fashion to the trade credits equation). According to the coefficient estimates in Table 1, trade credits affect imports, but imports do not affect trade credits. $\Delta 1$ (Trade Credits) is positive and statistically significant in the import equations, suggesting that the short-run causality from trade credits to imports was summarized by two quarters of data. On the other hand, none of the imports variables is significant in the trade credits equation.

Note that the signs and magnitudes of the coefficient estimates of the unconstrained estimation in Table 1 cannot be evaluated as correlations among contemporaneous variables. The negative (and insignificant) coefficients of lagged imports in the trade-credits equation appear counterintuitive given the findings in Rose \& Spiegel (2002) that higher bilateral trade is associated with higher bilateral lending. However, the coefficient estimates in Table 1 simply provide short-run lagged adjustment effects of imports on trade credits and do no imply any particular sign for the contemporaneous correlation between imports and trade credits; the contemporaneous correlation would depend on other static considerations such as the gravity-type variables (i.e. geography, currency, population, and political ties) documented in Rose \& Spiegel (2002). As any fixed effect is eliminated in the dynamic panel data, it is useful to examine next whether the effect of trade credits on imports continue to hold in the estimation segregated by regions and income groups.

According to the coefficient estimates in Table 2, the impact of trade credits on imports volume is significant only for Latin America \& the Caribbean and the Middle East \& North Africa regions. Earlier, Figures 1(c) and 2(c) showed that the trade credits to imports ratio has been declining, particularly for Latin America \& the Caribbean and Middle East \& North Africa regions. These findings and the regressions thus suggest that trade credits are declining in the regions where its impact is greater. The effect of trade credits on imports is weaker for East Asia \& the Pacific, East Europe and Central Asia, and South Asia, where trade credits to imports ratio display a relatively stable trend.

Table 3 reports the estimation segregated by income groups. The effects of trade credits on imports are significant only for the Middle and Low-income countries. Both groups also rely more on trade credits than the High- and Upper-income groups. This again suggests that trade credits display a larger and significant impact on the countries that depend more on it. Interestingly, however, we also see in Figure 2(c) that the trade credits/import ratio trends downward for the Middle-income countries, whereas it is rising sharply for the Low-income group. Presumably, the Middle-income group has increasingly broadened its sources of external finance away from trade credits as it moves up the income ladder and improves its domestic financial system. 
Table 2. Panel est Central Asia (EC), Latin America \& the Caribbean (LAC), Middle East and North Africa (MNA), and South Asia (SAR). Variables are in $\log$. $\Delta m$ denotes the first difference of lag $m$. The sample is a balance panel data covering semiannual periods from 1992 to 1997. Estimation uses the dynamic ${ }^{\infty}$ anel data framework. Standard errors are in parentheses. Symbol ${ }^{*}\left[{ }^{* *},{ }^{* * *}\right]$ denotes statistical significance at the $10 \%$

$[5 \%, 1 \%]$ level

\begin{tabular}{|c|c|c|c|c|c|c|}
\hline $\begin{array}{l}\text { Dependent variable: } \\
\text { Region: }\end{array}$ & $\begin{array}{l}\text { Imports } \\
\text { AFR }\end{array}$ & $\begin{array}{l}\text { Imports } \\
\text { EAP }\end{array}$ & $\begin{array}{l}\text { Imports } \\
\text { ECA }\end{array}$ & $\begin{array}{l}\text { Imports } \\
\text { LAC }\end{array}$ & $\begin{array}{l}\text { Imports } \\
\text { MNA }\end{array}$ & $\begin{array}{l}\text { Imports } \\
\text { SAR }\end{array}$ \\
\hline $\begin{array}{l}\text { Explanatory Variable: } \\
\Delta 1 \text { (Imports) } \\
\Delta 2 \text { (Imports) } \\
\Delta 3 \text { (Imports) } \\
\Delta 1 \text { (Trade Credits) } \\
\Delta 2 \text { (Trade Credits) } \\
\Delta 3 \text { (Trade Credits) }\end{array}$ & $\begin{array}{l}-0.068(0.098) \\
-0.090(0.077) \\
-0.335(0.074)^{* *} \\
0.055(0.070) \\
0.122(0.075) \\
0.015(0.074)\end{array}$ & $\begin{array}{c}-0.092(0.106) \\
-0.181(0.088)^{*} \\
-0.348(0.086)^{* *} \\
0.077(0.065) \\
-0.031(0.060) \\
0.042(0.057)\end{array}$ & $\begin{array}{l}-0.201(0.246) \\
-0.147(0.237) \\
-0.633(0.292)^{*} \\
-0.178(0.333) \\
-0.166(0.248) \\
-0.129(0.348)\end{array}$ & $\begin{aligned} 0.084(0.107) \\
-0.297(0.088)^{* *} \\
-0.106(0.107) \\
0.481(0.169)^{* *} \\
-0.001(0.201) \\
-0.279(0.170)\end{aligned}$ & $\begin{array}{c}-0.289(0.147)^{*} \\
0.132(0.120) \\
0.078(0.109) \\
0.240(0.084)^{* *} \\
-0.022(0.086) \\
-0.099(0.083)\end{array}$ & $\begin{array}{r}-0.294(0.179) \\
-0.046(0.183) \\
0.143(0.184) \\
0.158(0.196) \\
-0.241(0.258) \\
0.088(0.175)\end{array}$ \\
\hline $\begin{array}{l}\text { Observations } \\
\text { Number of Countries }\end{array}$ & $\begin{array}{r}200 \\
40\end{array}$ & $\begin{array}{l}85 \\
17\end{array}$ & $\begin{array}{r}25 \\
5\end{array}$ & $\begin{array}{r}150 \\
30\end{array}$ & $\begin{array}{l}65 \\
13\end{array}$ & $\begin{array}{r}30 \\
6\end{array}$ \\
\hline
\end{tabular}


Table 3. Panel estimation by income group. Income classification by the World Bank. Variables are in $\log . \Delta m$ denotes the first difference of lag $m$. The sample is a balance panel data covering semiannual periods from 1992 to 1997 . Estimation uses the dynamic panel data framework. Standard errors are

in parentheses. Symbol ${ }^{*}\left[{ }^{* *},{ }^{* *}\right]$ denotes statistical significance at the $10 \%[5 \%, 1 \%]$ level

\begin{tabular}{lcccc}
\hline $\begin{array}{l}\text { Dependent variable: } \\
\text { Income: }\end{array}$ & $\begin{array}{c}\text { Imports } \\
\text { HIGH }\end{array}$ & $\begin{array}{c}\text { Imports } \\
\text { UPPER }\end{array}$ & $\begin{array}{c}\text { Imports } \\
\text { MIDDLE }\end{array}$ & $\begin{array}{c}\text { Imports } \\
\text { LOW }\end{array}$ \\
\hline Explanatory Variable: & & & & \\
$\Delta$ (Imports) & $-0.246(0.227)$ & $-0.191(0.114)$ & $-0.201(0.112)$ & $-0.254(0.092)^{* *}$ \\
$\Delta$ (Imports) & $-0.448(0.347)$ & $-0.202(0.095)^{*}$ & $-0.376(0.081)^{* *}$ & $-0.139(0.068)^{*}$ \\
$\Delta 3$ (Imports) & $-0.429(0.316)$ & $-0.238(0.099)^{*}$ & $-0.125(0.075)$ & $-0.322(0.063)^{* *}$ \\
$\Delta$ (Trade Credits) & $-0.060(0.195)$ & $0.015(0.113)$ & $0.383(0.100)^{* *}$ & $0.153(0.061)^{*}$ \\
$\Delta 2$ (Trade Credits) & $-0.202(0.177)$ & $-0.121(0.121)$ & $0.013(0.088)$ & $0.065(0.062)$ \\
$\Delta 3$ (Trade Credits) & $0.194(0.149)$ & $0.191(0.173)$ & $0.018(0.077)$ & $0.078(0.061)$ \\
Observations & 25 & 140 & 175 & 215 \\
Number of Countries & 5 & 28 & 35 & 43 \\
\hline
\end{tabular}

As discussed earlier, one possible reason countries repay their debts is to avoid the discontinuation of their line of trade credits. Based on the coefficient estimates presented so far, it is plausible that a trade penalty exists. Its impact on imports could materialize within less than two quarters after sovereign debt default.

\section{Cross-country Estimation}

In this section, we conduct a robustness check using cross-country estimation. While the panel data estimation in the previous section provides a useful short-run pattern in the data, it lacks the control of other conditioning factors, of which the data are available only at a lower frequency. Working with the cross-section allows us to include other variables thought to influence imports and trade credits, including GDP, GDP per capita, and total liabilities to banks, while at the same time taking into account changes in global economic conditions over the sample periods.

All of the variables are now measured as the change between the three subperiods: 1991-1993, 1994-1996, and 2001-2003 (henceforth denoted in front of each variable by $\Delta$ ). For the estimation purpose, we have, at an annual frequency, the information for 120 countries on trade credits, imports, GDP, capita GDP, and total liabilities to banks. Table 4 reports the cross-country regressions, including also regional dummies. Overall, our estimation accounts for $55-62 \%$ of variation in the data. The coefficient estimates are consistent with those from the panel estimation. We find that the change of trade credits is positively associated with the change of imports. The outcome continues to hold whether we use the change between 1991-1993 and 1994-1996, or the decadal change between 1991-1993 and 2001-2003.

Next, we replace the dependent variable with the imports to GDP ratio, and the explanatory variable with trade credits to total liabilities to banks. The coefficient estimates are not significant. Presumably, this weak and negative finding is due to the scope of the sample and that we are able to consider only the interaction 
Table 4. Cross 5 country estimation Variables are measured as a percentage change between periods. Estimation uses the OLS. Standard

gerrors are in parentheses. Symbol ${ }^{*}\left[{ }^{* *},{ }^{* *}\right]$ denotes statistical significance at the $10 \%[5 \%, 1 \%]$ level

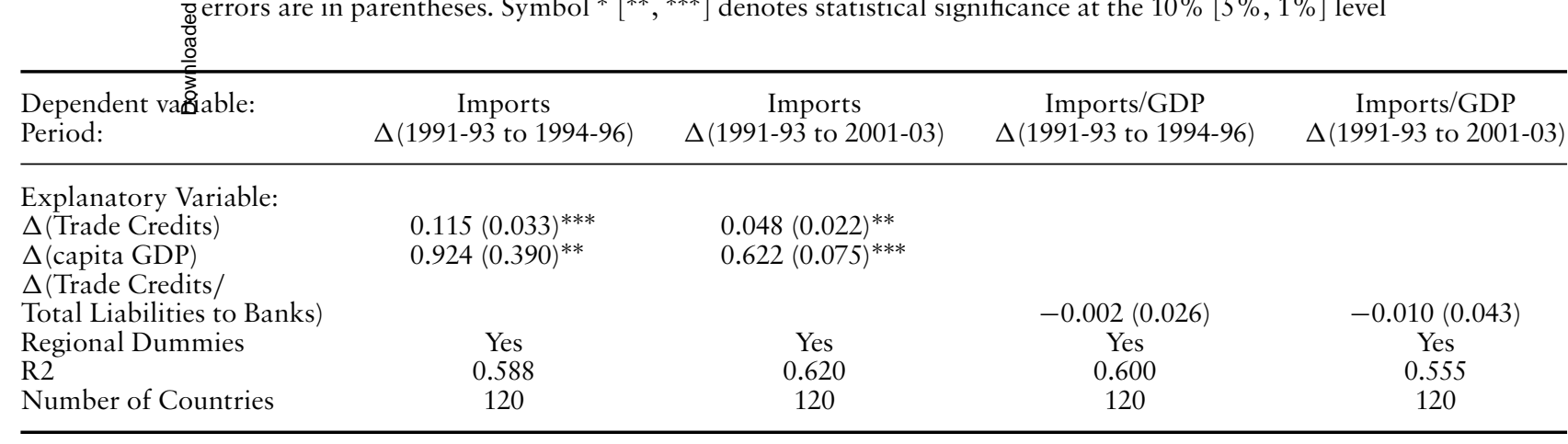


between developing-country debtors and their industrial counterparts. In addition, it is quite possible that the positive effect of trade credits is mitigated by the negative impact as it is also a burden in a country's total liabilities to foreign banks. It is not simple to fix this measurement error to be able to go deeper into the details. The availability of consistent panel and cross-section information at both high (monthly) and low (annual) frequency will therefore allow a useful extension.

Figure 3 summarizes the cross-country study, reporting the economic significance of trade credits and capita GDP on imports volume. We calculate the economic significance based on the coefficient estimates in Table 4 as the following. The first bar represents the impact of trade credits, measuring a percentage change of imports/GDP based on the mean in 1994-1996 of trade credits (US\$7.059 billion) and GDP (US\$127.850 billion). The standard deviation of the percentage change of trade credits for the period 1994-1996 is 132.647. Using the coefficient estimate of trade credits on imports from Table 4 panel 1 , which is 0.115 and statistically significant, the effect of +1 standard deviation change of trade credits is to increase imports by $[0.115 \times 132.647] \times(7.059 / 127.850) \approx 0.84 \%$ of GDP. The economic significance of trade credits on imports is stable and sizable at around 1\% of GDP between 1991-1993 and 1994-1996, as well as for the decadal change between 1991-1993 and 2001-2003. The capita GDP variable also explains much of the variation in the imports adjustment over the periods. Over the decade, the change in capita GDP will increase imports/GDP more than $3 \%$. Empirically, capita GDP tends to correlate with a host of macroeconomic and institutional conditions, including, for example, GDP growth, real exchange rate adjustment, openness, and political regimes. To single out the impact of these variables, a possible extension can focus on a country case (or group of countries), using a higher frequency (i.e. monthly) data.

\section{Summary}

One possible reason countries repay their debts is to avoid any disruption to commercial trade. Functioning mainly as a cross-border financial instrument, trade credits are often thought to increase the probability of sovereign debt repayment. The main findings of this paper are that (1) past trade credits help predict current imports, but past imports do not cause the future path of trade credits; (2) two quarters are sufficient to summarize the relevant intertemporal association between trade credits and imports. These findings confirm the dependence of developing countries on the provision of trade credits from their trading partners. That trade credits aid the incentive to repay is therefore supported by the data.

In practice, most trade credits are short-run liabilities between delegated commercial banks of importers and exporters. Our findings are sensible as the estimated time that potential trade penalties via reduction in trade credits could materialize is within less than two quarters. Any trade penalty is likely to be most effective when the debtor's gains from international trade are large, and the creditor country's small, but the costliness of possible trade sanctions to the creditor need not render them ineffective, and trade sanctions can be effective even if they 


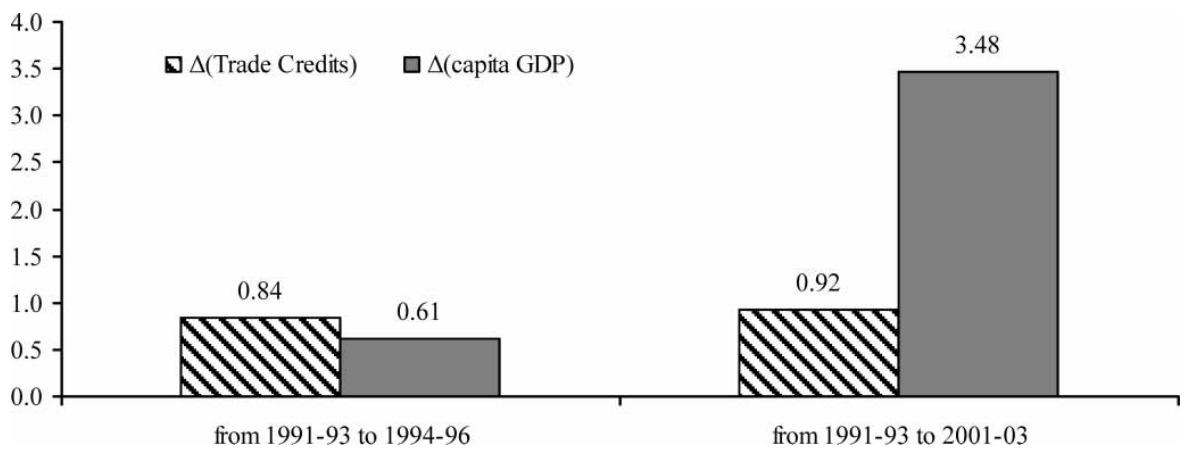

Figure 3. Measuring economic significance - the effect (\%) on imports of a one standard deviation change in trade credits. The calculation is based on the coefficient estimates in Table 4 as follows. The first bar represents the impact of trade credits, measuring a percentage change of imports/GDP based on the mean in 1994-1996 of trade credits (7.059 billion US\$) and GDP (127.850 billion US\$). The standard deviation of the percentage change of trade credits for the period 1994-1996 is 132.647. Using the coefficient estimate of trade credits on imports from Table 4 panel 1, which is 0.115 and statistically significant, the effect of +1 s.d. change of trade credits is to increase imports by $[0.115 \times 132.647] \times(7.059 / 127.850) \approx 0.84 \%$ of GDP

are not actually used (Eaton \& Engers, 1992). Hence, one may view our findings here as supportive of the notion that commercial trade and financial networks are intertwined.

Delving deeper into the details, exactly then how does a disruption in a country's financial system affect trade credits as a source of external finance? For example, should a country with stronger trade and financial ties with its trading partners (or creditors) be less affected by disruptions in the financial system because it might be better in securing trade-financing loans? The linkages between trade credits and imports could also depend on networks in international trade and bargaining power between trading partners. ${ }^{8}$ Exploration on trade finance deals data will also allow a useful extension and uncover other aspects of credit provision across countries. These challenges are left for future investigation.

\footnotetext{
${ }^{8}$ On trade and financial networks in international arena, see for example Rauch (1999), Forbes \& Chinn (2004), and Portes \& Rey (2005). On financial crises and international, see Cline (1987), Stephens (1998), and Ma \& Cheng (2003). Current data limitation does not allow a direct test on the association between bilateral (or between other grouping of countries, i.e. G7 and emerging markets) trade volume and bilateral trade financing amount. In particular, the Joint External Debt Hub (JEDH) data by BIS, IMF, OECD, and World Bank does not provide trade credit data by creditor. The JEDH adds together the data from both creditor and borrower and reports the total trade credit amount by the borrowing country because the creditor countries provide only official and official guaranteed trade credits - even if it was provided, the creditors' trade credit data underestimates borrower data as they only cover official and officially guaranteed non-bank trade credits (please also see http://www.bis.org/publ/bispap13.pdf). Nevertheless, without testing directly on the bilateral relationship, which is not permitted by the data availability, we expect the main findings to continue to hold. Our reading from trade financing magazines (i.e. Trade $\&$ Forfaiting Review; http://www.tfreview.com/) suggests that in practice the lending banks follow standard monthly trade financing rates. These rates will guide the pricing of trade loans for both small, financial-center, and large trade lending banks, including those in industrial countries, such as Barclays, Citigroup, Sumitomo Mitsui, and HSBC.
} 


\section{Acknowledgements}

The author would like to thank Joshua Aizenman, Swisa Ariyapruchya, James Rauch, and two anonymous referees for helpful comments and suggestions. Any remaining errors are the author's own.

\section{References}

Arellano, M. \& Bond, S. (1991) Some tests of specification for panel data: Monte Carlo evidence and an application to employment equations, Review of Economic Studies, 58(2), pp. 277-297.

Baltagi, B.H. (2001) Econometric Analysis of Panel Data (Chichester: Wiley).

Beck, T. (2002) Financial development and international trade: is there a link?, Journal of International Economics, 57, pp. 107-131.

Bulow, J.I. \& Rogoff, K. (1989) A constant recontracting model of sovereign debt, Journal of Political Economy, 97, pp. 155-178.

Cline, W.R. (1987) Mobilizing Bank Lending to Debtor Countries (Washington, DC: Institute for International Economics).

Dixit, A. (2003) Trade expansion and contract enforcement, Journal of Political Economy, 111(6), pp. $1293-1317$.

Eaton, J. (1986) Credit policy and international competition, in: P.R. Krugman (Ed.) Strategic Trade Policy and the New International Economics, pp. 115-145 (Cambridge, MA: MIT Press).

Eaton, J. \& Engers, M. (1992) Sanctions, Journal of Political Economy, 100(5), pp. 899-928.

Eaton, J. \& Gersovitz, M. (1981) Debt with potential repudiation: theoretical and empirical analysis, Review of Economic Studies, 48(2), pp. 289-309.

Forbes, K.J. \& Chinn, Menzie, D. (2004) A decomposition of global linkages in financial markets over time, Review of Economics and Statistics, 86(3), pp. 705-722.

Greif, A. (1993) Contract enforceability and economic institution in early trade: the Maghribi Traders' coalition, American Economic Review, 83(3), pp. 525-548.

Greif, A., Milgrom, P. \& Weingast, B.R. (1994) Coordination, commitment, and enforcement: the case of the merchant guild, Journal of Political Economy, 102(4), pp. 745-776.

Holtz-Eakin, D., Newey, W. \& Rosen, H.S. (1988) Estimating vector autoregressions with panel data, Econometrica, 56(6), pp. 1371-1395.

Judson, R.A. \& Owen, A.L. (1999) Estimating dynamic panel data models: a guide for macroeconomists, Economics Letters, 65(1), pp. 9-15.

Kletzer, K.M. \& Bardhan, P. (1987) Credit markets and patterns of international trade, Journal of Development Economics, 27, pp. 57-70.

Kletzer, K.M. \& Wright, B.D. (2000) Sovereign debt as intertemporal barter, American Economic Review, 90(3), pp. $621-639$.

Klimenko, M.M. (2002) Trade interdependence, the international financial institutions, and the recent evolution of sovereign-debt renegotiations, Journal of International Economics, 58, pp. 177-209.

Krueger, A.O. (2002) A New Approach to Sovereign Debt Restructuring (Washington, DC: International Monetary Fund).

Ma, Z. \& Cheng, L. (2003) The effects of financial crises on international trade. NBER Working Papers No. 10172, December.

Marin, D. \& Schnitzer, M. (2002) The economic institution of international barter, Economic Journal, 112, pp. 293-316.

Ozler, S. (1993) Have commercial banks ignored history? American Economic Review, 83(3), pp. 608-620.

Palmer, H. (1999) International Trade and Pre-export Finance: a Practitioner's Guide (London: Euromoney Books).

Phillips, P.C.B. \& Moon, H.R. (2000) Nonstationary panel data analysis: an overview of some recent developments, Econometric Reviews, 19, pp. 263-286.

Portes, R. \& Rey, H. (2005) The determinants of cross-border equity flows, Journal of International Economics, 65(2), pp. 269-296. 
Rauch, J.E. (1999) Networks versus markets in international trade, Journal of International Economics, 48, pp. $7-35$.

Rose, A.K. (2005) One reason countries pay their debts: renegotiation and international trade, Journal of Development Economics, 77(1), pp. 189-206.

Rose, A.K. \& Spiegel, M.M. (2002) A gravity model of sovereign lending: trade, default and credit. NBER Working Papers No. 9285, October.

Sarria-Allende, V., Preve, L.A. \& Love, Inessa (forthcoming) Trade credit and bank credit: evidence from recent financial crises, Journal of Financial Economics.

Stephens, M. (1998) Export credit agencies, trade finance, and South East Asia. IMF Working Papers WP/98/175.

Svaleryd, H. \& Vlachos, J. (2002) Markets for risk and openness to trade: how are they related? Journal of International Economics, 57, pp. 369-395.

Svaleryd, H. \& Vlachos, J. (2005) Financial markets, the pattern of industrial specialization and comparative advantage: evidence from OECD countries, European Economic Review, 49(1), pp. 113-144.

USDOC (2002) Letters of Credit (U.S. Department of Commerce). http://www.osec.doc.gov/ogc/ occic/letcred.html

\section{Appendix A.1. Data Source and Definition}

WDI $\equiv$ World Development Indicators Online by the World Bank DOTS $\equiv$ Direction of Trade Statistics by International Monetary Fund $\mathrm{JEDH} \equiv$ Joint External Debt Hub by BIS, IMF, OECD, and World Bank

\begin{tabular}{|c|c|c|c|}
\hline Variable & Frequency & Source & Description \\
\hline GDP & annual & $\begin{array}{l}\text { WDI line } \\
\text { NY.GDP.MKTP.KD }\end{array}$ & $\begin{array}{l}\text { Constant year } 2000 \\
\text { US\$ Gross Domestic } \\
\text { Product }\end{array}$ \\
\hline Capita GDP & annual & $\begin{array}{l}\text { WDI line } \\
\text { NY.GDP.PCAP.PP.KD }\end{array}$ & $\begin{array}{l}\text { Constant year } 2000 \text { US\$ } \\
\text { GDP per capita }\end{array}$ \\
\hline $\begin{array}{l}\text { U.S. GDP } \\
\text { deflator }\end{array}$ & annual & $\begin{array}{l}\text { WDI line } \\
\text { NY.GDP.DEFL.ZS }\end{array}$ & $\begin{array}{l}\text { Deflator with base year } \\
2000\end{array}$ \\
\hline Imports & quarterly & DOTS line 10170..DZD & $\begin{array}{c}\text { Current US\$ Imports } \\
\text { volume deflated by } \\
\text { U.S. GDP deflator }\end{array}$ \\
\hline Trade credits & quarterly & JEDH line $\mathrm{L}$ & $\begin{array}{l}\text { Current US\$ trade } \\
\text { credits deflated by } \\
\text { U.S. GDP deflator }\end{array}$ \\
\hline $\begin{array}{l}\text { Total } \\
\text { liabilities } \\
\text { to banks }\end{array}$ & quarterly & JEDH line $\mathrm{J}$ & $\begin{array}{l}\text { Current US\$ total } \\
\text { liabilities to banks } \\
\text { deflated by U.S. GDP } \\
\text { deflator }\end{array}$ \\
\hline
\end{tabular}

\section{Appendix A.2. Country List}

Region and income classification by the World Bank. ***, **, * codifies upper, middle, low-income, respectively. Africa(AFR), East Asia \& Pacific(EAP), Eastern Europe \& Central Asia(ECA), Latin America \& the Cribbean (LAC), Middle East 
and North Africa (MNA), and South Asia (SAR).

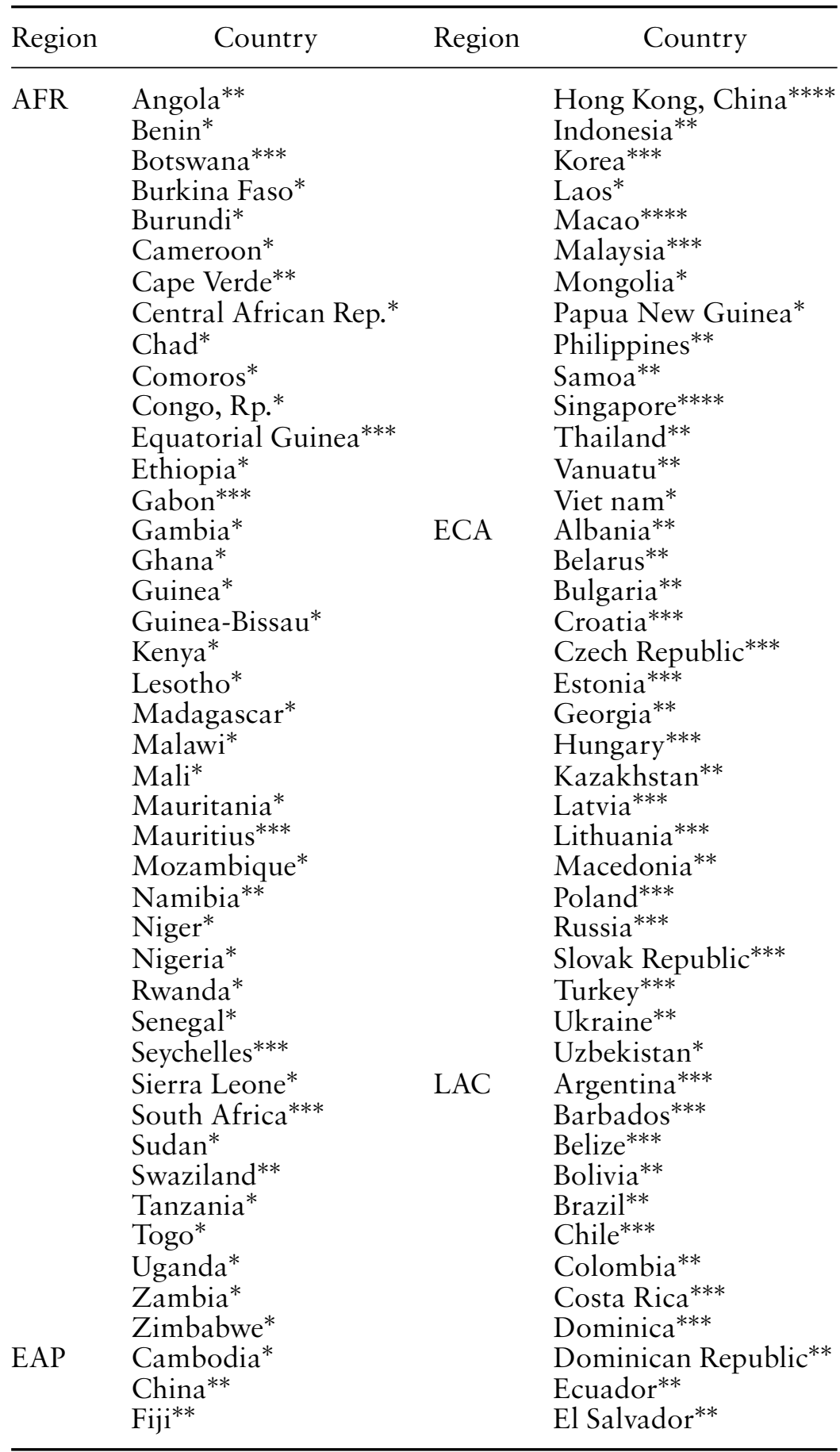




\begin{tabular}{|c|c|c|c|}
\hline Region & Country & Region & Country \\
\hline & Grenada*** & \multirow[t]{11}{*}{ MNA } & Algeria** \\
\hline & Guatemala** & & Egypt** $^{* *}$ \\
\hline & Guyana** & & $\operatorname{Iran}^{* *}$ \\
\hline & Haiti* & & Israel**** \\
\hline & Honduras ${ }^{* *}$ & & Jordan** \\
\hline & Jamaica $^{* *}$ & & Lebanon $* * *$ \\
\hline & Mexico*** $^{* * *}$ & & Morocco $^{* *}$ \\
\hline & Nicaragua* & & Oman*** \\
\hline & Panama*** & & Syria** \\
\hline & Paraguay $^{* *}$ & & Tunisia** $^{* *}$ \\
\hline & Peru ${ }^{* *}$ & & Yemen* \\
\hline & St. Lucia*** & \multirow[t]{5}{*}{ SAR } & Bangladesh* \\
\hline & St. Vncent \& Grenadines ${ }^{* * *}$ & & India* \\
\hline & Trinidad \& Tobago ${ }^{* * *}$ & & Nepal* \\
\hline & Uruguay*** & & Pakistan* \\
\hline & Venezuela*** & & Sri Lanka** \\
\hline
\end{tabular}

